\title{
Low doses of Gamma Radiation in Soybean
}

${ }^{1}$ José Gilmar Franco, ${ }^{2}$ Suely Salumita Haddad Franco, ${ }^{3}$ Caio Haddad Franco, ${ }^{4}$ Luisa Haddad Franco, ${ }^{5}$ Maria Abud Haddad Franco, ${ }^{1,2}$ Paula B. Arthur, ${ }^{1}$ Anna L. C. Villavicencio, ${ }^{1,2}$ Valter Arthur

${ }^{1}$ Institute of Energy and Nuclear Research (IPEN), Department of Radiation Technology Center, University of São Paulo. Box: 05508-000, São Paulo - SP, Brazil.

${ }^{2}$ Center For Nuclear Energy in Agriculture (CENA/USP), Department of Radiobiology and Environment, University of São Paulo, Box: 13416 - 000, Piracicaba SP. Brazil

${ }^{3}$ Department of Microbiology and Parasitology - Federal University of Sao Paulo (Unifesp), Rua Botucatu, 862, São Paulo - Box 04023-062, Brazil .

${ }^{4}$ Faculty of Medicine of Jundiai, Rua Francisco Telles, 250, Box 13.202-550, Jundiai - SP., Brazil.

${ }^{5}$ Faculty of Medicine of Unicesumar, Av. Guedmar, 1610, Box 87050-900, Maringá - PR., Brazil.

Correspondence Author: José Gilmar Franco, Institute of Energy and Nuclear Research (IPEN), Department of Radiation Technology Center, University of São Paulo. Box: 05508-000, São Paulo - SP, Brazil..

Received date: 12 June 2018, Accepted date: 4 September 2018, Online date: 13 September 2018

Copyright: $\odot 2018$ José Gilmar Franco, This is an open-access article distributed under the terms of the Creative Commons Attribution License, which permits unrestricted use, distribution, and reproduction in any medium, provided the original author and source are credited.

\begin{abstract}
The degree of radio sensitivity depends mainly on the species, the stage of the embryo in the irradiation, the doses used and the criteria used to measure the effect. One of the most common criteria for evaluating seed radio sensitivity is to measure the plant's average yield. The dried soybean seeds were exposed to low doses of gamma radiation from Cobalt-60, Gammacell-220 type source, at a dose rate of $0.245 \mathrm{kGy}$. In the first stage the objective was to study the effects of radiation stimulation on germination, growth and plant production. Four doses of radiation were applied as follows: 0 (control); 25 ; 50; 75 and 100 Gy. Seed germination harvested seed number and total yield were evaluated to identify the occurrence of stimulation. The low doses of gamma radiation in the seeds that stimulate the production were doses of 25, 50 and 75 Gy. In the second stage the objective was also to study the effects of radiation stimulation on germination, growth and plant production. In this case, a treatment with three doses of radiation was applied as follows: 0 (control); 12.5 ; 25.0 and 50.0 Gy. Seed germination harvested seed number and total yield were evaluated to identify the occurrence of stimulation. The number of soybean seeds and plants were handled following the standard seed production in Brazil. There is evidence in the results showing that the use of low doses of gamma radiation can stimulate the germination and the production of plants.
\end{abstract}

Key words: Irradiation, soybean, stimulation, production.

\section{INTRODUCTION}

Soybeans crops are the main grains produced in the world, ranking fourth in global production volume and first among the "major oil seeds," participating in the worldwide agricultural economy. According to the United States Department of Agriculture data, soybean was grown in the 2012/13 crop in an area of approximately 103 million hectares, with total production of 239 million tons; estimated data for $2013 / 14$ show an increase of $6.67 \%$ in the area, which may cause an increase of up to $17.87 \%$ of total world production. Stimulation effects on germination, growth and production with the use of low doses of gamma radiation have been reported by many authors (Luckey, 1980; Abdel-Fattah, 1993).

Studies showed the radiation effects after seed treatment with different doses $(6.25,10.2$ and 60 Gy) on germination process and plant development of distinct maize varieties wheat, barley, oat, lupine, colza and turnip. Observations were made during germination in order to predict a final production increase; however, it was concluded that this foresight was not possible, because the stimulant dose production did not coincide with those that had stimulated germination (Degner and Schacht, 1984).

The irradiation of plants may result in death, growth inhibition, altered metabolism, morphological abnormalities and mutations. The magnitude of the effect depends on the radiation characteristics of the studied species and age of the plants. The study of the effects of ionizing radiation in plants can be conducted in pollen, embryos, seeds, roots, etc. The analysis parameter can be the plant growth, morphological and histological changes, effect on hormones, etc. (Casaret, 1986).

During the decade between 1974 and 1984, many experiments on radio-induced mutation in soybean were performed in order to obtain mutant strains, some of which were highly radiosensitive (Smutkupt; Woongpiyasatid; Lamssejan, 1985). The degree of radio sensitivity of a plant embryo depends on the species and the developmental stage of the embryo during irradiation and the criteria used to measure the biological effect. One of the most common criteria to evaluate the seed radio sensitivity is to measure the height of the plant after germination (Casaret, 1986).

Dormant seeds are less radiosensitive than the seeds with developing embryos, probably due to its quiescent state characterized by diminished cell division or differentiation ratio and also due to their low water content (Casaret, 1986). LD100 is defined as the radiation dose required to kill all the plants studied, LD50 is defined as the radiation dose which kills one-half of the studied population of plants (Hall, 1994). L..

The objective of this work was to evaluate the effects of gamma radiation doses to stimulate the germination, growth and production of soybean Glycine max 
Dry soybean seeds were exposed to low doses of gamma radiation from Cobalt-60, type Gammacell-220 source, at a dose rate of $0.245 \mathrm{kGy}$ to study the effects of radiation stimulation on plant germination, growth and production. In the first stage (2015), four radiation doses were applied as follows: 0 (control); 25; 50; 75 and $100 \mathrm{~Gy}$. Seed germination and collection of number, weight and total yield were evaluated to identify the occurrence of stimulation. The seeds were seeded after irradiation the next morning in previously prepared pots. The experimental design used in the analysis of data variance was the experiment in blocks (Vieira, 1999), with three replicates (3 blocks) and 5 different treatments (4 radiation doses and control).

In the second stage of the study, four doses of treatment radiation were applied as follows: 0 (control); $12.5 ; 25$ and 50 Gy. The percentage of seed germination, weight and total yield were evaluated to identify the occurrence of stimulation. For the numerical data collected during the observations, the Tukey test was used (Vieira, 1999 and Pimentel, 1990) to compare the mean values of the different blocks. Soybean seeds and plants were handled following the standard seed production in Brazil. The seeds were also sown the following morning in previously prepared pots. The experimental design used in the analysis of data variance was the block experiment (Vieira, 1999) with three replicates (3 blocks) and 4 different treatments ( 3 radiation doses and control). For the numerical data collected during the observations, the Tukey test was also used to compare the mean values of the different blocks (Vieira, 1999 and Pimentel, 1990).

\section{RESULTS AND DISCURSSION}

Listed in Table 1, the mean values of the percentage of the total twinning and obtained seeds of treatments with increasing doses of gamma radiation from Cobalt-60. The table results indicate that the treatments with doses of 25,50 and 75 Gy showed statistically significant differences when compared to other treatments, but among themselves the values were similar.

Table 1: Average number of seeds harvested from seed irradiated with increasing doses of gamma radiation from Cobalt-60.

\begin{tabular}{|c|c|c|c|}
\hline Doses (Gy) & Number of planted seeds & Germination percentage & $19 \pm 2.2 \mathrm{~b}^{*}$ \\
\hline 0 & 9 & $98 \pm 1.0 \mathrm{a}$ & $22 \pm 1.9 \mathrm{a}$ \\
\hline 25 & 9 & $97 \pm 0.9 \mathrm{a}$ & $22 \pm 2.3 \mathrm{a}$ \\
\hline 50 & 9 & $97 \pm 0.7 \mathrm{a}$ & $22 \pm 30 \mathrm{a}$ \\
\hline 75 & 9 & $98 \pm 1.2 \mathrm{a}$ & $16 \pm 27 \mathrm{c}$ \\
\hline
\end{tabular}

*Means by the same letter are not statistically different at the $5 \%$ Tukey test.

Listed in Table 2, the mean values of the percentage of the total emerged sprouts and obtained seeds of treatments with increasing doses of gamma radiation from Cobalt-60. The table results indicate that the treatment with dose of 50.0 Gy was the one that presented the best result in all evaluated parameters when compared to other treatments. But in the parameter mean number of healthy seeds no significant differences were observed when compared to 25.0 Gy dose. These results are similar to those of when irradiated seeds of soya with doses of 25, 50 and 75 Gy (Franco, 1999; Franco, et al., 2015 and Franco, 2018).

Table 2: Average number of seeds harvested germinated plants, number of pods and production parameters from seed irradiated with increasing doses of gamma radiation from Cobalt-60.

\begin{tabular}{|c|c|c|c|c|c|c|c|}
\hline $\begin{array}{c}\text { Doses } \\
(\mathrm{Gy})\end{array}$ & $\begin{array}{c}\text { Number of } \\
\text { planted seed }\end{array}$ & $\begin{array}{c}\text { Number of } \\
\text { germinated seeds }\end{array}$ & $\begin{array}{c}\text { \% of germinated } \\
\text { plants }\end{array}$ & $\begin{array}{c}\text { Number of pods } \\
\text { per plant }\end{array}$ & $\begin{array}{c}\text { Number Weight } \\
\text { of seeds (g) }\end{array}$ & $\begin{array}{c}\text { Number of } \\
\text { seeds }\end{array}$ & $\begin{array}{c}\text { Number of } \\
\text { healthy seeds }\end{array}$ \\
\hline 0 & 9 & $4.0 \pm 0.4 \mathrm{~b}^{*}$ & $66.6 \pm 8.1 \mathrm{c}$ & $33.3 \pm 5.6 \mathrm{a}$ & $6.6 \pm 1.1 \mathrm{~b}$ & $60.0 \pm 7.9 \mathrm{~b}$ & $36.3 \pm 4.8 \mathrm{~b}$ \\
\hline 12.5 & 9 & $4.6 \pm 0.6 \mathrm{~b}$ & $77.7 \pm 9.5 \mathrm{~b}$ & $223 \pm 4.3 \mathrm{~b}$ & $6.7 \pm 1.2 \mathrm{~b}$ & $55.3 \pm 6.2 \mathrm{c}$ & $49.0 \pm 5.5 \mathrm{a}$ \\
\hline 25.0 & 9 & $3.6 \pm 0.2 \mathrm{c}$ & $61.1 \pm 7.6 \mathrm{~d}$ & $19.0 \pm 3.9 \mathrm{~b}$ & $3.9 \pm 0.3 \mathrm{c}$ & $34.0 \pm 3.1 \mathrm{~d}$ & $22.6 \pm 3.2 \mathrm{c}$ \\
\hline 50.0 & 9 & $5.0 \pm 0.8 \mathrm{a}$ & $83.3 \pm 9.6 \mathrm{a}$ & $36.0 \pm 5.7 \mathrm{a}$ & $7.5 \pm 1.9 \mathrm{a}$ & $67.3 \pm 8.2 \mathrm{a}$ & $52.3 \pm 5.7 \mathrm{a}$ \\
\hline
\end{tabular}

*Means by the same letter are not statistically different at the $5 \%$ Tukey test.

According to (Luckey, 1980 and Wiendl et al., 1995), low doses of radiation have the ability to stimulate bio-systems reversing the effects with increasing dosage. This theory called hormesis, still not very well understood and widely debated, could explain the observed peak growth increasing dosages until $0.10 \mathrm{kGy}$ when loss of plants height values occurs.

In total opposition to the hormesis theory is the ALARA principle of radiological protection, which claims that any radiation dose is harmful to the organic material, independent of its intensity.

Still citing by Luckey, 1980, post-harvested experiments with distinct radiation dosage yielded good results with wheat, soybeans, corn, potato, among others by the process of irradiating the seeds or tubers with low doses before sowing.

\section{Conclusions:}

From the results, we observed the low doses of gamma radiation in the seeds that stimulated the production were doses of 25,50 and 75 Gy. Additionally, doses of 12.5 and $50 \mathrm{~Gy}$ increased significantly the number of germinated seeds and the production of grains.

\section{REFERENCES}

Abdel-Fattah, M.A., 1993. Stimulation effect of gamma radiation on two tomato cultivars and their first generation Hybrid. Ph.D. Thesis. University of Alexandria, Faculty of Agriculture.

Badr, H.M., A.A. Alsadon and A.R. Al-Harbi, 1997. Stimulation effects of gamma radiation on growth and yield of two tomato Lycopersicon esculentum, Mill. cultivars. J. King Saudi Univ. v. 9, Agric. Sci., 2: 277-286.

Casaret, A.P., 1968. Radiation Biology. New Jersey: Prentice Hall, 368

Degner, W. and W. Schacht, 1984. Untersuchungen über die spezifische Wirkung kleiner Dosen ionisierender Strahlung auf Saatgut von Kulturpflanzen. VII. Mitteilung: Untersuchungen über Keimungsverlauf und Ertragsbildung bei gamma-bestrahltem Saatgut verschiedener Kulturarten. Radiobiol. Radiother., 25(1): 83-92.

Franco, S.S.H., 1999. Interrelação de radiohormese e a incidência de insetos pragas na cultura de milho .Zea mays L. (Ph .D. These) - Universidade de São Paulo, 72 .

Franco, J.G., 2018. Influência de diferentes doses de radiação gama $\left(\mathrm{Co}^{60}\right)$ em sementes de soja Glycine max (1.) visando aumento de produtividade. (Ph. D. Thesis) - Instituto de Pesquisas Energéticas e Nucleares, 75. 
Franco, J.G., S.S.H. Franco, C.H. Franco, V. Arthur, P.B. Arthur and A.L. Villavicencio, 2015. Effects of gamma radiation in soybean. International Nuclear Atlantic Conference - INAC 2015, São Paulo, S.P., 4.

Hall, E.J., 1994. Radiobiology for the radiologist. 4. ed. Philadelphia: J.B. Lippincott,. 478.

ICRP., 1990. International Commission Radiological Protection. Oxford: Pergamon Press, 201p.

Luckey, T.D., 1980. Hormesis with Ionizing Radiation, 222. CRC Press de Boca Raton.

Smutkupt, S., A. Woongpiyasatid and S. Lamssejan, 1985. Soybean mutants induced by gamma radiation. Environ. Mutagen., 7(3): 41.

Pimentel, F., 1990. Estatística experimental. 13. ed. Piracicaba: Nobel, 468.

Vieira, S., 1999. Estatística experimental. 2. ed. São Paulo: Editora Atlas, 185.

Wiendl, F.M., F.W. Wiendl, J.A. Wiendl and V. Arthur, 1995. Increase of onion yield through low dose of gamma irradiation of its seeds. Radiation Physics and Chemistry, Great Britain, 46(4-6): 793-795. 